\title{
The Pupil's Creativity is inspired by Experience through Electronic Media: Empirical Study in Yogyakarta
}

\section{Suparmi}

A Student of Post- Graduate Program in Department of Education Science, Yogyakarta State University, Indonesia, suparmip@gmail.com

\section{Siti Partini Suardiman}

Department of Education Science, Yogyakarta State University, Indonesia, partinisuardiman@gmail.com

\section{Asri Budiningsih}

Department of Education Science, Yogyakarta State University, Indonesia, asri_budi@uny.ac.id

This study aims to describe the development of creativity in elementary schoolage pupils inspired using electronic media through self-actualization. Qualitative research was designed with a multicase study and the selection of informants using purposive sampling methods. Data collection involved 30 informants consisting of six pupils, six parents, two principals, ten teachers, two mentors and four peers. Indepth interviews, observations, documentation are used simultaneously to collect data. Data is analyzed qualitatively. The results showed that: (1) the development of pupil's creativity through self-actualization. Four pupils began when sitting in four grade of elementary school, one pupil since sitting in kindergarten and one pupil starting before entering school. Pupils fulfil the requirements of creativity by having a level of intelligence, verbal intelligence and creative behaviour, (2) teachers in the learning process assisted by electronic media to make it easier for children, (3) pupils have been inspired by electronic media (television, computers, internet) in themselves-actualizing. Pupils used to electronic media for entertainment, academic and other information as new knowledge. Finally, this study found that the development of pupil's creativity is inspired by the electronic media accompanied by parents or adults.

Keywords: electronic media, television, computer, internet, pupil's creativity

\section{INTRODUCTION}

Nowadays, media are very important part to convey the messages that have functions as sending information, communication, education, and even recreation (Tirtarahardja \& 
Sulo, 2010). Hence, it has currently embedded and cannot be separated with the human life. There are two types of media, including electronic media and non-electronic media. Electronic media is a media that uses electronic energy in its use to access its content, such as recording devices, multimedia, Television, Computers, Smartphones. Nonelectronic media is media that we use without the aid of electronic devices, such as magazines, newspapers, books, bulletin boards, planel boards, magnetic boards, demonstration boards, flyer. Electronic media that drives various technology products with various functions called gadgets (Merrin, 2014). Electronic media in its development including Information and Communication Technology (ICT) is a key factor in the future, if used creatively (Semenov, Pereverzev, Bulin-Sokoloeva, 2005).

Learning in schools assisted by computers, smartphones, computer-based and internetbased have been sustained. Technology-assisted learning could enhance pupil activity interactions (Neo \& Neo, 2004), improve pupils' understanding and learning (Neo, Neo \& Xiao-Lian, 2007), increase the development of scientific concept construction and analogical reasoning (Chuang, \& She, 2013), ease of reading books (Yang, Hwang, Hung, \& Tseng, 2013), and children could identify new skills (Khoo, \& Churchill, 2013). Learning with smartphone features helps middle school pupils become independent, interact, interdependence, trust self-esteem, self-esteem, mutual support, and understanding in the context of reading (Alzubi, \& Singh, 2018). Learning using video games could improve visual spatial skills, such as regarding visual, mental rotation and target localization, improving problem solving skills (Schmidt, \& Vandewater, 2008). Learning Mathematics used social media could work more effectively (Abirin, \& Obra Jr., 2018). Subrahmanya, et al., (2000; 2001), the positive impact of using gadgets were better motor skills, increased cognitive skills, facilitating learning tasks, children were happier, educate early and are skilled at competing.

The use of media has a negative and positive impact. The negative impact of the influence of advertisements from television on electronic media can influence children to behave according to the program being aired. Television shows have a negative effect on children's behavior (Hameed, Waqas, Aslam, Bilal, \& Umair, 2014; Faraday, Vijayalakshmi, Vasantha, Kanchana, \& Lawrence, 2016; Jusoff, \& Sahimi, 2009; Samaniego \& Pascual, 2007). Physical and psychological effects not only from television, but also from the use of games on the computer. Telmesani, Ahmad \& Telmenasi (2017), added the impact of using technology, namely: 1) physically including eye health, hearing problems, obesity, sleep deprivation habits, 2) mental health such as neurological disorders and attention disorders, 3) social habits such as isolation, lack of social skills and ties, violations, lack of empathy, lack of limitations, lack of privacy, lack of awareness of reality. Television gives pupils a world of distorted imagery, because children have difficulty distinguishing reality from fantasy.

Anticipation of the negative effects of electronic media, need assistance by parents or adults around children. Parental assistance is more optimal learning outcomes (Kirkorian, Wartella, \& Anderson, 2008). The use of videogames makes children more creative (Jakcson, 2012). The internet also influences individual creativity by directing to create products and solutions (Gutiérrez-Leefmans, 2015). Previous media use influenced the development of interest in writing, learning their craft, and producing and 
testing ideas in fiction writers (Paton, 2011). The use of tablets increases the creative skills of middle school pupils (Kim, Park, Yoo, \& Kim, 2016). Television significantly develops creativity, especially for children, who are in the formative stage of creative development (Kant, 2012a). Seeing TV shows related to the creativity of middle pupils shows a positive relationship (Kant, 2012b).

The Indonesian National Education System Law states that pupil's creativity needs to be developed. The development of creativity is the main goal in education (Wicaksono et al., 2017). In fact education in Indonesia shows that pupil have not been able to optimize scientific thinking skills (OECD, 2014, 2016). Electronic media in learning is still less used for elementary school pupils. For this reason, any electronic media that can inspire the development of pupils creativity needs to be done. Since when do pupils begin to actualize creativity. What are the functions of electronic media for pupils as devotee. The use of electronic media regularly can stimulate pupils' creativity.

\section{Creativity}

In a globalizing world, it is currently needed a creative generation. Creativity is a manifestation of individuals who have been fully functional and creative to be able to self-actualize (Maslow, 1999). Bloom's puts creativity in the highest dimensions of cognitive processes (Anderson \& Krathwohl, 2001). Creativity and education have occurred in Europe, America, Australia and East Asian countries, to support competition in the economic field. Developing countries are labeled as user countries by developed economies. Developing countries are not expected to underestimate creativity if they want to compete with developed economies (Shaheen, 2010). Lin (2011), in developing children's creativity, it is recommended to use the confluence approach (in accordance with countries in Asia) which consists of three interrelated elements, namely: (1) creative teaching, (2) teaching for creativity, and (3) learning creative. Bierly III, Kolodinsky, \& Charette, (2009) creative personalities have relativistic behavior, namely determining moral solutions that are not based on general moral rules, but rather on the specifications of each situation. Azadegan, Bush, \& Dooley, (2008) support design creativity as a dynamic ability depends on personality traits. Maslow (1999) creativity is the legacy of every person from birth, and works in varying ways with psychological health.

According to Whitehead (2009), Creativity principle of novelty, Golann (1973) Creativity has been described as related to, or equetable with, intelligence, productivity, positive mental health, and originality. Munandar (1977) Creativity is defined as a process that manifests itself in fluencey, in flexibility as well as in originality of thinking. Hurlock (1978), creativity is a person's ability to produce any composition, product, or idea that is basically new and previously not known to its makers. DeBono (1991) creativity is related to lateral thinking. Lateral thinking is related to the rebuilding of old patterns (in understanding) and raised by something new (creativity), Mayer, (1999). Authenticity and usefulness. Sternberg (2003); Sternberg \& Zhang, (2011) everyone is a creator with various levels of creativity. In investment theory, the level of creativity requires everyone's resources involving six different but interrelated resources, namely: intellectual ability, knowledge, thinking style, personality, 
motivation, and environment. Compton, (2010) designed in three levels of creativity representing a continuum that can combine creativity, namely: referring to selfexpression, combining individualism and combinational creativity, genius-level creativity.

Factors that influence the development of creativity according to Gomez (2007), are: convergent and divergent thinking, environment, tools to test ideas, reflective thinking and thought evaluation. Rhodes (1961), known as four P creativity, namely product, process, person and press. Wu, et al (2014) include: personal character, family background, school, community. According to Seo, Lee and Kim (2005), it covers three aspects, namely cognitive, personality, and environmental conditions. Amabile (1997) there are three aspects in individual creativity, namely expertise, creative thinking skills, and intrinsic task motivation, each of which is very important for creativity and the three aspects interact with each other. In this research the aspect used is the theory used of Seo, Lee and Kim.

\section{METHOD}

This research is a qualitative study with a multicase approach and is naturalistic because researchers do not give treatment. The research location was at two Public Elementary School (PES) Yogyakarta. The both of PESs have pupils who are able to themselvesactualize to regional and national levels. The process of collecting data involved 30 informants consisting of six pupils, six parents, two principals, ten teachers, two mentors and four peers. Purposive sampling is used in selecting informants. The criteria for pupils informants in this study were; (1) have intelligence Quotient (IQ) above average, (2) have creative behavior an average, (3) dare to themselves-actualize at the district level. The process of determining informants was based on initial information on pupil's self-actualization at the district level, then the researchers conducted IQ tests, verbal creativity tests (VCT) using Wechsler Norm and gave questionnaires for creative behavior. Data collection techniques with in-depth interviews, observation, and documentation. Research instruments are researchers with tools to guide interviews, record tools, and field notes. The validity of research data includes internal validity, reliability/consistency, external validity, research ethics. Data is analyzed qualitatively since the beginning of data collection with steps: organizing data, coding and reducing data, grouping, finding media types and concluding.

\section{FINDINGS}

The results of data reduction from in-depth interviews of the pupils and informants are presented in the description. Pupils background came from two PES at Yogyakarta. Each pupil has creativity that is actualized in various fields. The results of pupils' performance and daily activity data are shown in Table 1.

Table 1

Pupils Background

Pupil Performance and Daily Activities

A $\quad$ Second place in the National Math Olympic and helps making handicrafts brooches

B Participants at the district-level football athletes and make toys that are useful to dispel the birds in the rice fields, commonly called "long-longan." 


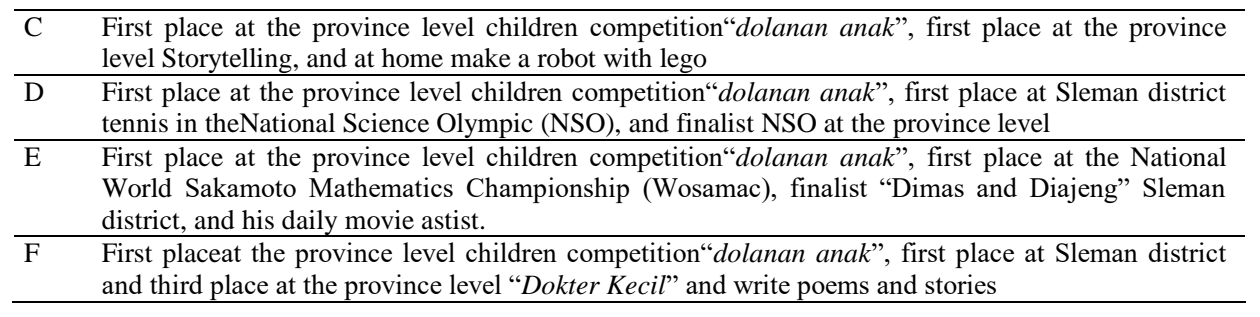

Measurement of intelligence was carried out with the Intelligence Quotient Test (IQT) of Slosson Full-Range Intelligence Test (S-FRIT) by Bob Algozzire et al. Verbal creativity test (VCT) from Utami Munandar using the Wechsler Norm. Pupil had an IQ level and VCT above the average with the Wechsler Norm. The results of the pupil's IQ and VCT data collection process are presented in table 2. The measurement of pupil's creative behavior is obtained based on the scale of the creative behavior of Utami Munandar. The maximum score of creative behavior scale is $1 \times 32=32$ and the minimum score is $0 \times 32=0$, meaning: 16 , standard deviation: $32-0$ : $6=5.33$. Thus, the pupils has moderate behavior. The moderate score after being trace by interview turns out that the curiosity item about events around the pupils shows that pupils are not interested. The pupils' turned out to be more of a content in electronic media so they were looking for answers also in electronic media. Detailed scores are obtained as in table 3 .

Table 2

IQ dan VCT Pupil with Wechsler Norm

\begin{tabular}{llllll}
\hline Pupil & Age & IQ score & Category & VCT Score & Category \\
\hline A & 12 years & 147 & Very superior & 137 & Very superior \\
B & 11 years & 128 & Superior & 111 & High average \\
C & 10 years & 136 & Very superior & 122 & Superior \\
D & 11 years & 136 & Very superior & 115 & High average \\
E & 10 years & 143 & Very superior & 120 & Superior \\
F & 11 years & 144 & Very superior & 124 & Superior \\
\hline
\end{tabular}

Table 3

Creative Behavior

\begin{tabular}{lllll}
\hline Category & Formula & Range & Freq & $\mathrm{s}$ \\
\hline High & $(\pi+1 \mathrm{SD}) \leq \mathrm{X}$ & $\leq 21,33$ & - & - \\
Medium & $(\pi-1 \mathrm{SD}) \leq \mathrm{X}<(\pi+1 \mathrm{SD})$ & $10,67 \leq \mathrm{X}<21,33$ & 6 & $100 \%$ \\
Low & $\mathrm{X}<(\pi-1 \mathrm{SD})$ & $<10,67$ & - & - \\
\hline
\end{tabular}

Low $\quad \mathrm{X}<(\pi-1 \mathrm{SD})$
$\pi=$ average
$\mathrm{SD}=$ standard deviation
$\mathrm{X}=$ score factual

The six pupils in the development of creativity are supported, except the pupils of case $\mathrm{B}$ and E. Case of A, C, D and F, pupils themselves-actualize from normative kindergarten. In the sense that the pupils conducts school activities without participating in activities outside of school. Meanwhile for case B, when he was still in kindergarten, he has self-actualized by playing drum bands at the sub-district level. After transferring to PES fourth grade, he was active again by participating in district level football. Case 
$\mathrm{E}$ is active in self-actualizing from the age of five. Activities started from the Fashion show and drew up to third grade PES. In the fourth grade, he reduced drawing activities and changed clothes to become film and extracurricular activities at school.

The PES in learning using multimedia assistance. Learning multimedia assistance is used to facilitate understanding of material. There are computer laboratory facilities at PES number I, so pupils C, D, E, and F are used to operating computers for learning purposes. The computer laboratory facilities are often used by pupils to find information on the internet by mentoring ICT teachers. Meanwhile for the others do not have laboratory facilities. Pupil A,C, D, E, and F are used to using computers at home. Meanwhile pupil B cannot operate the computer because there are no facilities at home. Each pupil has a different time but the difference between individual is not significantly different. Pupils interact with electronic media can be collected and on average for a week is quite a lot. The use of electronic media is done by pupils at home, at school and at friends' houses. Table 4 shows the time range of viewing and using electronic media.

Table 4

The Time Spent with Electronic Media

\begin{tabular}{lll}
\hline Pupils & hour/week & Viewing and using Electronic Media \\
\hline A & 20-25 hours & Television, laptop, internet with laptop, internet with smartphone \\
B & $11-15$ hours & Television and offline game \\
C & $16-23$ hours & Television, laptop, internet with laptop, internet with tabs \\
D & $15-20$ hours & Television, laptop, internet with laptop, internet with tabs \\
E & 22-30 hours & Television, computer, internet with computer, internet with smartphone \\
F & 10-25 hours & Television, internet with laptop \\
\hline
\end{tabular}

Pupil A see the Upin-Ipin cartoon program after school. In the afternoon, accompanied by his sister, he saw a Naruto cartoon. Searching for mathematics learning material is done on other weeks and days if the laptop internet is not used by his father. His mother's smartphone was used to find the latest brooch models on the sidelines. $\mathrm{He}$ watched TV in the afternoon after school, namely Si Bolang (Adventure Boy) and in the afternoon Naruto cartoons, as well as Sunday to his friend's house to play offline games together. Pupil C, watched TV before goes to school while waiting to be taken to school. After school rested and then make a lego, usually see TV cartoons. Tabs are used to search for stories and play Face Book (FB) or search for stories. The use of the internet on laptops is done on Sundays or school holidays and to make power points to present. Pupil D rarely watched TV. Tabs is used to play agility games. Father's laptop is borrowed to do assignments for class presentations. If it's Sunday, get holiday with friends playing games offline at the E's house or playing Lego, playing computer and playing skateboard at C's house. Pupil E rarely watched TV seen only by Naruto cartoons. Computers at home to download games online and play offline, and download good movies. E's closeness with electronic media (computers and games) since the age of two years when E was addicted to play games. At the age of three to four years, pupils are addicted to play online games so their mothers must be at internet cafes from seven to eight in the morning. An addiction began to decrease when attending school at the Kindergarten with the help a teacher who wanted to start reducing playing online games gradually until he could sleep at 12.00. Furthermore, parents give lots of activities so pupil is tired and easy to sleep before 12 o'clock at night. Pupil F watched 
TV every day, like Barbie cartoons before leaving school. After School she watched the Bima-Bima, the Marsya and the Bear cartoons and before bedtime she watched any programs. Father's laptop is borrowed to do assignments for class presentations.

\section{DISCUSSION}

Pupil A learns to operate a laptop independently by often seeing his father work using a laptop, and at that time he was still in grade four aged ten years. Every day, he always practice math problems for the Olympics that are taken from the internet. These exercises regularly will make him has the ability to think creatively and be skilled in solving math problems in various ways. The mentor of mathematics olympiad in the province stated that he had uniqueness in working on math practice questions. The uniqueness is that he has the ability to work on various ways to solve problems, finish quickly and correctly where these methods are not owned by a child of the same age. It is from uniqueness and creative thinking skills that brings the pupil to the national scene in the mathematics olympiad.

Pupil B only has electronic media TV at home. He watched TV often accompanied by his mother while keeping a grocery shop. Every Sunday he places his best friend to play offline games. After he whached TV shows the "Si Bolang" program he makes toys "long-longan" (bamboo canon). Long-Longan is a sound instrument made of used cans of rice pest with a certain amount and size, given a lighter from a gas lighter with sepiritus fuel. If the press is pressed it will produce a loud sound like a firecracker and is used to drive birds in the fields. He makes long-longan used his father's workshop tool. Some of works were distributed to neighboring rice fields and not sold. For parents, children of the same age as pupil and have work that help parents and the environment is a success and needs to be motivated to do more in their environment. It is an exercise to solve problems so that adults later pupil will be more skilled at getting solutions in life.

Pupil $\mathrm{C}$ is a pupil who is quiet, firm, and likes to read anything, both from books, magazines and from the internet. Reading pleasure makes him different from his friends, and dares to self-actualize in the storytelling. His fondness for playing games and watching cartoons can him's inspire in implementing in the characters his like by making robots from used cardboard. Expressions from cartoon characters and games are implemented also in self-actualization in storytelling.

Pupil D is a pupil who is independent, assertive and often helps his friends if there is a discrepancy between friends or fights. Assertiveness in decision making, fair and favored by friends and he makes the rules in the game, both at recess and at sports hours. It was also stated by the sports teacher that the pupil often changed the rules in especially traditional sports games so that friends who were left behind could come along to play together. The rules of the game are often modified so that the number of friends left behind can play together. His behavior was inspired by electronic media such as cartoons and playing dexterity games. Frequently playing dexterity games D's inspire strategies in playing tennis and also often make game rules with friends at school.

Pupil E has an FB for learning animation, and drawing, because there are many friends who are learning slowly, who come from Semarang and Jakarta. He tried to draw 
cartoon characters in his imagination. Besides drawing professionally as a film artist is a coincidence. Starting when E's sister took part in a fashion show competition at the shopping center, when she had to appear the sister cried not stopped, then her mother asked him to hold hands and walk on the stage and turned out to be the champion. After being tracked, the championship turned out not because of the sister appearance but the unique appearanceof him. The uniqueness is inspired by characters from the games played. The E's appearance of a long hair, because from a child he does not want his hair to be cut, in a ponytail behind with a messy bangs. Since then he has often had roles in films, like roles a national figure in childhood in the Djendral Soedirman film. Since entering elementary school the appearance has not been unique because of rules that do not allow pupil to have long hair. For professionalism in the roles, he has been included in a children's theater at Taman Budaya Yogyakarta (TBY). Various characters are played and the mentors feel challenged. According to the E's mentor is a child who is able to adapt the situation quickly, is able to improvise beyond the direction of the mentor and it actually strengthens the character being played. Discussing with the figures that are displayed, he has many ideas for the development of scenarios. Between the tight schedule of the school playing movies and playing theater he is still continuing the habit of opening the internet from school to seven at night. The habit of playing offline games is still carried out from one to two hours before going to bed either on his mother's computer or smartphone. Accompanying parents who are addicted to offline and online games can shift into inspiration for pupils to be more creative.

Pupil F from childhood always gets a bedtime story from her mother. Since she had a younger brother and second grade elementary school, she no longer got the story and switched watching TV. The favorite cartoon character is a generous, helpful, kindhearted daughter and many friends. The princess character always fills her days in making friends and making poems and stories. The imagination of the princess in the real-life pupil, where the pupil can self-actualize by following a small docotr competition. The habit of helping her friends who fainted during the ceremony, entertain her with stories. She also like to give an example of a clean and healthy life by washing hands before and after doing activities and eat lots of vegetables and fruit. Her father's laptop wa borrowed to do school assignments including presentations in participating in a small doctor competition. She is very proud of her success in self-actualization by participating in the competition. This makes her more actively sharing with her friends.

Children's creativity in six pupils can be grouped into creativity thinking skills by themselves-actualization differently. In the process of actualizing each child differently in starting. In general they adjust according to the child's development, however, especially those who struggle to self-actualize in front of other people besides family or out of habit determine a different time. Self-actualization is carried out with performance at both the regional and national levels. Pupil A with unique ideas in solving mathematical problems and can also make broaches. He dared to appear in front many people since sitting in fourth grade. Pupil B in its accuracy watching TV can make "long-longan" products. He dared to appear in front of a lot of people since sitting in kindergarten. Pupil C has sound, gestures and expressions capable of storytelling and also making robots from used paperboard. He dared to appear in front many people 
since sitting in fourth grade. Pupil D makes new rules in the game with friends in its class. He dared to appear in front of people since sitting in fourth grade. Pupil E was able to portray a number of prominen figure in childhood in the films. He dared to appear in front many people since the age of five. And pupil $\mathrm{F}$ becomes a small doctor who can realize her imagination to be a useful pupil for herself and others around her. She dared to appear in front of people since sitting in fourth grade.

Based on the research data obtained can be describer in the framework in figure 1.

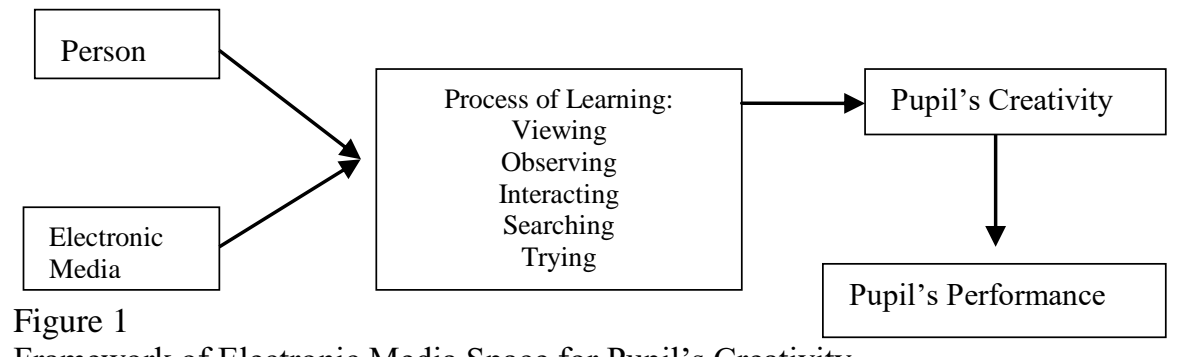

Framework of Electronic Media Space for Pupil's Creativity

Based on IQ and VCT scores (see table 2), creative behavior (see table 3), and electronic media as an environmental condition (see table 4) pupils can be independent to understand the material well. Pupils with ability requirements can apply creative skills in their lives (Seo, Lee and Kim, 2005). Electronic media are used by pupils to fill their spare time to find material that fits their learning needs, such as presentation assignments in class and looking for information about the preparation of competitions to be followed (Tirtarahardja \& Sulo, 2010). The process of learning from electronic media are to see, search, observe, interact and try. Trained and accustomed to the learning process, pupils are honed to be skilled creative thinking. The results of practice and habituation in watching and using the media to produce new and unique ideas, and can modify something to suit the material around it (Whitehead, 2009). The ideas can lead pupils to self-actualization. Meanwhile the produced by pupils are beside helping others, it also increases parents' income. And then pupils' creativity is the ability to slove proplems that provide original ideas or adaptive ideas in expression and fungtion.

The pupil's creative thinking skills in facilitating themselves in different ways. All pupils are themselves-actualizing by participating in the lowest competition at the district level (see table 1). Meanwhile differences are individual, like pupil of A with unique ideas for solving mathematical problems. B with its careful view that TV can make products "long-longan" to drive birds in the fields, C with sound, gestures and expressions is capable of storytelling and also making robots from used paperboard. D often makes new rules in the game with friends in its class. $\mathrm{E}$ is able to portray a number of characters to be able to portray figure in their childhood. And F by being a small doctor the pupil can realize her imagination to be a pupils who is useful to herself and others around her. The C, D, E, and F pupils have their own uniqueness, even though they are collected by the school in the "dolanan anak" game but individually they have different performance and preferences. Pupils C, D, E playing games can increase creativity (Jakcson, 2012). Pupil A uses the internet to solve mathematical problems 
(Gutiérrez-Leefmans, 2015). Pupil B watching tv can make a long-longan tool to banish birds and F is inspired by children's stories (Kant's, 2012a). Although the media seen and used is the same, but each individual perceives what he/she sees in his/her daily life is different. Playing games both online or offline and television which are both educative and practicable and in accordance with developments can stimulate pupils' creativity. And then the experience of using electronic media regularly helps pupils to practice their creativity.

\section{CONCLUSION}

Pupil's daily activities are often shared with electronic media. Electronic media, such as viewing TV, play games with computers, tabs and smartphones. Pupils use electronic media to (1) entertain themselves by watching cartoons, children's programs, playing games, (2) looking for material for the completion of homework given by the teacher, (3) looking for information to answer other curiousities to increase pupils insight. (4) Pupils have the ability to solve problems that give original ideas or adaptive ideas in expression and function. The development of pupil's creativity through selfactualization, four pupils start when sitting in the fourth grade of elementary school, one pupil while sitting in kindergarten, and one pupil starts before entering school. Pupils fulfill the criteria of creativity by having a level of intelligence, verbal intelligence above average, and average creative behavior, (5) the teacher in the learning process uses the help of electronic media to make it easier for children to understand the material (6) the six pupils are inspired by electronic media (television, computer, internet with computer, internet with smartphone) in actualizing themselves, accompanied by parents or adults. Finally in this study it was found that the six pupils had the ability to acquaint themselves inspired by electronic media. Educational games and television programs need to be developed to stimulate pupils in exploring theirs' creativity, so that creativity becomes sustainable.

\section{REFERENCES}

Abirin, S. G., \& Obra Jr., M. R. (2018). Development and Use of social media-based mathematics instructional module for grade 7 pupils of geras integrated school. New Media and Mass Communication, 72, 31-59.

Alzubi, A. A. F., \& Singh, M. K. M. (2018). The impact of social strategies through smartphones on soudi arabia leaner's socio-cultural autonomy in EFL reading context. International Electronic Journal of Elementary Education, 11(1), 31-40.

Amabile, T.M. (1997). Motivating creativity in organizations: on doing what you love and loving what you do. California Management Review, 40(1), 42.

Anderson, L. W., \& Krathwohl, D. R. (Ed.). (2001). A taxonomy for learning, teaching, and assessing. New York: Longman.

Azadegan, A., Bush, D., \& Dooley. K. J. (2008). Design creativity: Static or dynamic capability? Int. J. of Op \& Pro. Ma., 28(7), 636-662. doi:10.1108/01443570810881794.

Bierly III, P. E., Kolodinsky, R. W., \& Charette, B. J. (2009). Understanding the complex relationship between creativity and ethical ideologies. Journal of Business Ethics, 86, 101-112. 
Chuang, M. H., \& She, H. C. (2013). Fostering 5th grade pupils' understanding of science via salience analogical reasoning in on-line and classroom learning environments. Educational Technology \& Society, 16(3), 102-118.

Comptom, A. (2010). The rise and fall of creativity in English education. British Education Studies Association, 2(2), 28.

Debono, E. (1991). Berfikir lateral (Judul Asli: Lateral thinking). Jakarta: Erlangga.

Faraday, M. K., Vijayalakshmi, S., Vasantha, S., Kanchana, T., \& Lawrence, W. (2016). Impact of television food advertising on unhealthy food preferences and eating behaviour among children: A systematic review. Int. J. of Home Science, 2(1), 167-173.

Golann, S. E. (1973). Psychological study of creativity. In D. B. Norton (Ed.), Creativity theory and research. New Haven, Conn: College \& University Publishers.

Gomez, J. G. (2007). What do we know about creativity? The J of Ef. Teac, 7(1), 31-43.

Gutiérrez-Leefmans, M., (2015). Is internet making us more creative? Ciencia Ergo-Sum, 23(2), 182-187.

Hameed, A., Waqas, A., Aslam, M. N., Bilal, M., \& Umair, M. (2014). Impact of TV advertisement on children buying behavior. Int. J. of Hum. and Soc. Sci, 4(2).

Hurlock, E. E. (1978). Psikologi perkembangan jilid 2 edisi keenam. Jakarta: Erlangga.

Jackson L. A., Witt, E. A., Games, A. I., Fitzgerald, H. E., \& Eye, A. V. (2012). Information technology use and creativity: findings from the children and technology project. Computer in Human Behavior, 28, 370-376.

Jusoff, K., \& Sahimi, N.N. (2009). Television and media literacy in young children: Issues and effects in early childhood. International Education Studies, 2(3),

Kant, R. (2012a). Television and creativity. On. Int. Interd. Res. J, 2(3).

Kant, R. (2012b). a study of creativity of secondary school children as a correlate of some television viewing habits I. J. Modern Edu. and Computer Science, 10, 33-39.

Khoo, K. Y., \& Churchill, D. (2013). The framework of viewing and representing skills through digital text. Educational Technology \& Society, 16(3), 246-258.

Kim, H. J., Park, J. H., Yoo, S., \& Kim, H. (2016). Fostering creativity in tablet-based interactive classrooms. Educational Technology \& Society, 19(3), 207-220.

Kirkorian, H. L., Wartella, E. A., \& Anderson, D. R. (2008). Media and young children's learning. The Future of Children, 18(1), 39-61.

Lin, Y-S. (2011). Fostering creativity through education-a conceptual framework of creative pedagogy. Scientific Research, 2(3), 149-155

Maslow, A. H. (1999). Toward a psychology of being: creative in self-actualizing people. New York: John Weley \& Sons.

Merrin, W, (2014). The rise of the gadget and hyperlucid media. Cult. Politics, 10(1).

Mayer, R. E. (1999). Fifty years of creativity research. In R. J. Sternberg (Ed.), Handbook of creativity (pp. 449-460). Cambridge: Cambridge University.

Munandar, S. C. U. (1977). Creativity and education. Jakarta: Dikti Depdikbud.

Neo, T. K., \& Neo, M. (2004). Integrating multimedia into the Malaysian classroom: Engaging pupils in interactive learning. TOJET, 3(3), art: 4. 
Neo, M., Neo, T. K., \& Xiao-Lian, G. T. (2007). A constructivist approach to learning an interactive multimedia course: Malaysian pupils' perspectives. Australasian Journal of Educational Technology, ,23(4), 470-489.

OECD. (2014). PISA 2012 results. Washington: OECD Publishing.

OECD. (2016). PISA 2015 result in focus. Washington: OECD Publishing.

Paton, E. 2011). Communication and creativity: How does media usage influence those who create media texts? International Journal of Communication 5, 101-116.

Rhodes, M. (1961). An analysis of creativity. Phi Delta Kappan, 42(7), 305-307.

Samaniego, C. M., \& Pascual, A. C. (2007). The teaching and learning of values through television. Review of Education, 53, 5-21.

Schmidt, M. E., \& Vandewater, E. A. (2008). Media and attention, cognition, and school achievement. The Future of Children, 18(1), 39-61.

Semenov, A., Pereverzev, L., \& Bulin-Sokolova, E., (2005). Information and communication technology in schools. France: UNESCO.

Seo, H. A., Lee, Eun A., \& Kim, K. H. (2005). Korean science teachers' understanding of creativity in gifted education. Journal of Advanced Academics, XVI(2/3), 1-21.

Shaheen, R. (2010). Creativity and education. Scientific Research, 1(3), 166-169.

Sternberg, R.J. (2003). Wisdom, intelligence, and creativity synthesized. Cambridge: Cambridge University.

Sternberg, R. J., \& Zhang, L. F. (2011). Revisiting the investment theory of creativity. Creativity Research Journal. 23(3), 229-238. doi: 10.1080/10400419.2011-595974.

Subrahmanyam, K., Greenfield, P., Kraut, R., \& Gross, E., (2000). The impact of home computer use on children's activities and development. The Future of Children and Computer Technology, 10(2), 123-144.

Subrahmanyam, K., Greenfield, P., Kraut, R., \& Gross, E., (2001). The impact of computer use on children's and adolescents' development. App Dev. Psyc., 22, 7-30.

Telmesani, M., Ahmad, W., \& Telmesani T. M., (2017). The impact of technology on minors: a survey-based study. Australian J. of Busi., Soc. Sci. and Inf. Tec., 3(2) 78-90.

Tirtarahardja, U., \& Sulo, S.L. (2010). Pengantar pendidikan. Jakarta: Rineka Cipta.

Whitehead, A. N. (2009). Filsafat Proses, proses dan realitas dalam kajian kosmologi. Yogyakarta: Kreasi Wacana.

Wicaksono, I., Wasis, \& Madlazim. (2017). The effectiveness of virtual science teaching model (VS-TM) to improve pupil's scientific creativity and concept mastery on senior high school physics pupil. J. of Baltic Science Education, 16(4), 549-561.

Wu, H. Y., Wu, H. S., Chen, I. S., \& Chen, H. C. (2014). Exploring the critical influential factor of creativity for college students: A multiple criteria decision-making approach. Thinking Skills and Creativity, 11, 1-21.

Yang, C. C., Hwang, G. J., Hung, C. M., \& Tseng, S. S. (2013). An evaluation of the learning effectiveness of concept mapbased science book reading via mobile devices. Educational Technology \& Society, 16(3), 167-178. 